temperature is a trifle above the formation point of siloxicon.

From this we deduce the following figures:

Decomposition point of $\mathrm{SiC}$ to graphite $2220^{\circ} \pm 20^{\circ}$;

Formation of crystalline $\mathrm{SiC}$ I $820^{\circ} \pm 20^{\circ}$;

Formation of siloxicon $540^{\circ} \pm 30^{\circ}$.

The value for siloxicon is not established within as close limits as the others because of greater difficulty in telling where the zone really begins. All these values were checked by repeated runs.

Tucher's figure for graphite agrees exactly with ours, and his lower figure for $\mathrm{SiC}$, when corrected for the error due to the use of a graphite tube, comes within $10^{\circ}$ of our value. One figure, $1980^{\circ}$, obtained by him for this point is $160^{\circ}$ out because of the difference in the gradients in tube and furnace. This shows how large an error disregard of this point may introduce into temperature measurements in electric furnace work.

We have not attempted to fix any formation temperature for the so-called "Amorphous Carborundum" that is said to occur between the zones of crystalline $\mathrm{SiC}$ and of siloxicon, as there is no way of telling where the "amorphous SiC" zone begins or ends. Belief in the existence of this seems to have been handed down through the literature from the first work of Mulhauser. ${ }^{\text {I }}$

He analyzed a sample taken just outside the crystalline $\mathrm{SiC}$ zone, and after long treatment with $\mathrm{HF}$ and ignition, found it to correspond fairly well with the formula SiC. Potter ${ }^{2}$ has shown that siloxicon is attacked by $\mathrm{HF}$ and ignition with elimination of $\mathrm{Si}$ and $\mathrm{O}$, leaving a residue that approximates the formula $\mathrm{SiC}$. It seems very doubtful if amorphous $\mathrm{SiC}$ is formed in the commercial furnace, the zone outside the crystallized $\mathrm{SiC}$ probably being a series of complex oxycarbide compounds or solid solutions grouped under the name of siloxicon.

This work was done at Cornell University in the Spring of Igro under the direction of Prof. Bancroft, to whom the writer's best thanks are due.

Detroit, Mich., Feb., 1911

\section{ANALYSES OF CHARACTERISTIC NORTHWEST TIMBER SOILS.}

By J. S. Jones.

Received January 23, 1911

In the northwestern states large areas of cut and burned-over timber lands are being rapidly cleared and brought into a state of cultivation. For the most part these lands have produced splendid growths of white and yellow pine, fir, tamarack, and cedar. They will, in time, become of great importance to the agricultural development of the Northwest. In many localities they have already reached a stage in their development which indicates, that, as a class, the timbered soils of the Northwest will present problems peculiar to themselves. As a first step to a better understanding of these lands, we have

$1 Z$. anoew. Chem., 1893, 641; J. Am. Chem. Soc, 15, 411 (1893).

2Trans. Am. Electrochem. Soc., 12, 191 (1907). recently made complete analyses of samples representing several distinct soil types, embraced in the timber belt of north Idaho, locally referred to as the Pan Handle. Since up to this time no data have been published relative to the composition of any of these timber lands, we submit the following analyses in the belief that they will be of interest to others engaged in soil investigations.

If comparisons are suggested by these analyses, it should be noted that the lands in question lie entirely in the humid section of the state. The fine soil only (that which passed the meshes of a $\mathrm{r} / 2 \mathrm{~mm}$. sieve) was used for analysis. The samples were digested for ten hours in a boiling water bath with hydrochloric acid of I.II5 sp. gr., Io cc. of acid being used for each gram of soil. The analysis of the hydrochloric acid solutions, in the main, was conducted in accordance with the methods outlined by the Association of Official Agricultural Chemists. The humus determinations were made on solutions filtered through Pasteur-Chamberland filter tubes.

Table I.-Percentage Composition of Timber SoIls. ${ }^{1}$

Bench Land.

\begin{tabular}{|c|c|c|c|c|c|c|c|}
\hline \multirow[b]{2}{*}{$\begin{array}{c}\text { Laboratory } \\
\text { number. }\end{array}$} & & \multirow[b]{2}{*}{$360 f$} & \multirow[b]{2}{*}{204} \\
\hline & $360 a$ & $360 b$ & $360 c$ & $360 d$ & $360 e$ & & \\
\hline Coarse soil.. & & & & & 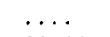 & $\cdots$ & 30.00 \\
\hline Fine soil.... & 100.00 & 100.00 & 100.00 & 100.00 & 100.00 & 100.00 & 70.00 \\
\hline \multicolumn{8}{|c|}{ Chemical Analysis of Fine Soll. } \\
\hline $\begin{array}{l}\text { nsoluble } \\
\text { matter... }\end{array}$ & 84.690 & 84.030 & 82.550 & 82.230 & 78.830 & 84.520 & 82.79 \\
\hline Potash $\left(\mathrm{K}_{2} \mathrm{O}\right)$ & 0.318 & 0.283 & 0.302 & 0.310 & 0.360 & 0.321 & 0.30 \\
\hline Soda $\left(\mathrm{Na}_{2} \mathrm{O}\right)$ & 0.229 & 0.226 & 0.276 & .282 & 0.292 & 0.276 & 0.24 \\
\hline Lime $(\mathrm{CaO})$ & 0.407 & 0.436 & 0.590 & .407 & 0.918 & 0.415 & 0.81 \\
\hline \multicolumn{8}{|l|}{ Magnesia } \\
\hline$(\mathrm{MgO}) \ldots$ & 0.623 & 0.516 & 0.623 & .734 & 0.846 & 0.878 & 0.42 \\
\hline \multicolumn{7}{|l|}{ Iron Oxide } & 2.26 \\
\hline $\begin{array}{l}\text { Alumina } \\
\left(\mathrm{Al}_{2} \mathrm{O}_{3}\right) \ldots . . \\
\text { Phosphotic }\end{array}$ & 6.039 & 6.275 & 8 & .655 & .943 & 6.139 & 7.46 \\
\hline acid $\left(\mathrm{P}_{2} \mathrm{O}_{5}\right)$ & 0.285 & 0.305 & 0.302 & 0.425 & 0.237 & 0.271 & 0.43 \\
\hline $\begin{array}{l}\text { Sulphur tri- } \\
\text { oxide }\left(\mathrm{SO}_{3}\right)\end{array}$ & trace & trace & trace & trace & trace & trace & 0.04 \\
\hline $\begin{array}{l}\text { Carbon di- } \\
\quad \text { oxide }\left(\mathrm{CO}_{2}\right)\end{array}$ & & & & & & & \\
\hline matter... & 4.300 & 4.676 & 4.930 & 5.580 & 7.770 & 3.957 & 5.70 \\
\hline Tota & 100.381 & 100.047 & 99.721 & 99.973 & 100.016 & 100.297 & 100.45 \\
\hline Reaction. & $\begin{array}{l}\text { slightly } \\
\text { acid. }\end{array}$ & $\begin{array}{l}\text { slightly } \\
\text { acid. }\end{array}$ & $\begin{array}{l}\text { slightly } \\
\text { acid. }\end{array}$ & $\begin{array}{l}\text { slightly } \\
\text { acid. }\end{array}$ & $\begin{array}{l}\text { slightly } \\
\text { acid. }\end{array}$ & $\begin{array}{l}\text { slightly } \\
\text { acid. }\end{array}$ & $\begin{array}{l}\text { slightly } \\
\text { acid. }\end{array}$ \\
\hline ggen & 044 & 54 & 0 & 0.080 & 170 & 0.042 & 0.10 \\
\hline Humus. . . . . & 0.702 & 0.773 & 0.740 & 1.730 & 1.620 & 0.542 & 1.36 \\
\hline \multicolumn{8}{|l|}{$\begin{array}{l}\text { Humus nitro- } \\
\text { gen p.c. in }\end{array}$} \\
\hline \multicolumn{8}{|c|}{ Humus nitrogen } \\
\hline p.c. in soil. & 0.034 & 0.034 & 0.032 & 0.057 & 0.107 & 0.028 & 0.08 \\
\hline
\end{tabular}

The samples whose analyses appear in Table I, represent to a depth of I $_{5}$ inches the soils of typical bench lands in the northern most county of the state. Samples No. $360 a-360 f$, inclusive, were taken at various places along the "divide" which separates the valleys of the Pend d'Oreille and Kootenai Rivers, and which here has an elevation of approximately 2000 feet. The crest of the "divide" is perhaps I 50 feet higher than the broad valleys on either side. More precisely the area represented by these samples lies from twenty

${ }^{1}$ For the analyses which are recorded in 'rable I, credit is due $\mathrm{Mr}, \mathrm{H}$ P. Fishburn 
to twenty-five miles northeast of the town of Sandpoint. A large portion of it will be utilized in the immediate future for orchard purposes. Physically, the surface soil may be described as a fine sandy loam. This at a depth of $20-24$ inches shades into a light clay loam. A vertical excavation to a depth of ro-I 2 feet failed to reveal any material change in the physical characteristics of the under soil. A large portion of the area has been fire-swept, the blackened stumps and prostrate trunks of trees still bearing testimony to the splendid growth of yellow pine and cedar which it has produced.

Sample No. 204 represents similar bench land on the west side of Pend d'Orielle Lake, and approximately ten miles southeast of the town of Sandpoint. This bench has an elevation of I50-200 feet greater than the level of the lake. From it the heavy timber has been logged and a dense growth of underbrush has taken its place. This section has not recently been burned over.

\begin{tabular}{|c|c|c|c|c|c|}
\hline Laboratory number. & $145 a$ & $145 b$ & $145 c$ & $145 d$ & $145 e$ \\
\hline Coarse soil. . . . . . . . . & & & 35.00 & 8.00 & 30.00 \\
\hline ine soil. ............... & 100.00 & 100.00 & 65.00 & 92.00 & 70,00 \\
\hline \multicolumn{6}{|c|}{ Chemical Analysis of Fine Soll. } \\
\hline Insoluble matter. & 74.36 & 43.40 & 70.05 & 67.26 & 64.09 \\
\hline Soluble silica. . . . . . . . . . . & 12.15 & 26.28 & 11.96 & 12.14 & 15.60 \\
\hline Potash $\left(\mathrm{K}_{2} \mathrm{O}\right) \ldots \ldots \ldots \ldots \ldots$ & 0.66 & 0.44 & 0.25 & 0.35 & 0.39 \\
\hline Soda $\left(\mathrm{Na}_{2} \mathrm{O}\right), \ldots \ldots \ldots \ldots$ & 0.45 & 0.34 & 0.57 & 0.39 & 0.53 \\
\hline Lime $(\mathrm{CaO}) \ldots$ & 0.90 & 0.10 & 0.63 & 0.61 & 0.58 \\
\hline Magnesia (MgO) . . . . . . . . & trace & trace & trace & trace & 0.74 \\
\hline Iron oxide $\left(\mathrm{Fe}_{2} \mathrm{O}_{3}\right) \ldots \ldots \ldots \ldots$ & 3.04 & 4.44 & 3.27 & 3.70 & 4.35 \\
\hline Alumina $\left(\mathrm{Al}_{2} \mathrm{O}_{3}\right) \ldots \ldots \ldots \ldots$ & 5.86 & 10,13 & 6.45 & 7.53 & 5.32 \\
\hline Phosphoric acid $\left(\mathrm{P}_{2} \mathrm{O}_{5}\right) \ldots \ldots \ldots$ & 0.09 & 0.15 & 0.56 & 0.28 & 0.28 \\
\hline Sulphur trioxide $\left(\mathrm{SO}_{3}\right) \ldots \ldots$ & none & none & none & none & none \\
\hline Carbon dioxide $\left(\mathrm{CO}_{2}\right) \ldots \ldots \ldots$ & $\ldots$ & $\cdots$ & $\cdots$ & $\cdots$ & $\ldots$ \\
\hline Volatile matter. . . . . . . . & 3.09 & 14.37 & 6.09 & 6.23 & 7.81 \\
\hline Total. . & 100.60 & 99.65 & 99.83 & 98.49 & 99.69 \\
\hline Total nitrogen & none & 0.16 & 0.08 & 0.11 & 0.17 \\
\hline
\end{tabular}

Samples No. $145 a-145 e$, inclusive, represent the bottom lands on the south side of the Pend d'Orielle River not far from the Idaho-Washington State line. This area has been cleared of a heavy growth of yellow pine, cedar, and underbrush. Like the bench land previously mentioned it is being developed for orchard purposes.

No. $4_{45} a$ represents a very light colored soil. Near the river it appears as a surface soil, but for the most part it is the characteristic subsoil of that section. This sample was taken to a depth of 15 inches. No. I $45 \mathrm{C}$ represents a soil of similar character farther back from the river. This one apparently results from the first coming very close to the surface, and having incorporated with it more or less of the alluvium carried down from the adjacent hillsides. Nos. $145^{b}, 145^{d}$, and $145^{e}$ are representative of alluvial and colluvial soils carried into the valley from the near-by hills, and deposited evenly to a considerable depth upon No. I45a. These samples were likewise taken to a depth of $I_{5}$ inches.

Still another type of timber land is represented in our analyses. This characterizes extensive areas of the higher lands embraced in and bordering the Coeur d'Alene Indian Reservation on the south and south- east. This district is covered with a heavy growth of yellow pine and fir. It is very rolling in character, but has an average elevation of 2500-3000 feet. The soil, in depth and physical properties, resembles very closely the prevailing types of the adjacent open prairie country, also a very rolling one, known locally as the "Palouse."

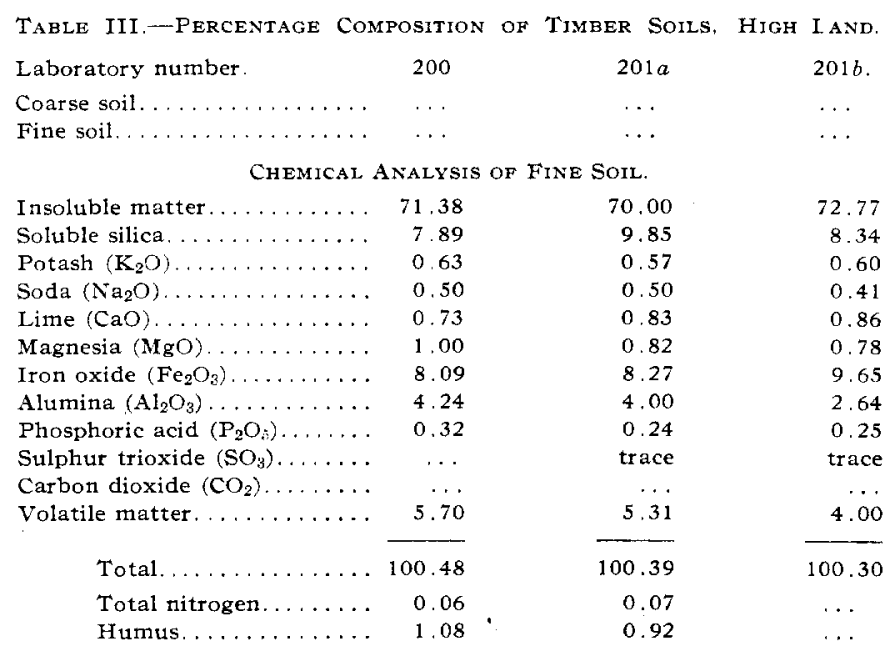

No. 200 represents a district of somewhat greater elevation than that represented by either of the others.

No. 20I $a$ represents the yellow pine lands more particularly, and was taken to a depth of 24 inches on a southwesterly slope. No. $20 \mathrm{I} b$ was taken to an even greater depth on a north hill slope, and is typical of the fir lands. Both Nos. $201 a$ and $201 b$ represent cut-over timber lands, but neither one has ever been in cultivation. Soil in adjacent fields and identical in character with that represented by $20 \mathrm{I} a$ has been in cultivation for several years and grows darker in color with cultivation. Cultivated soil similar to that represented by No. $20 \mathrm{I} b$ has not changed perceptibly in color during the several years it has been under cultivation. It has also been noticed that soils represented by No. zor $a$ compact readily, and that those represented by No. $20 \mathrm{r} b$ persistently remain loose and open. On the crest of the hills these soil types blend. When cleared of stumps and underbrush this land will be converted into grain and timothy farms.

With soil investigators, an opinion seems to be prevalent that pine forest soils, as a class, are weak in the essential elements of plant nutrition. The analyses recorded above, however, indicate very clearly that extensive areas of typical pine forest soils of the Northwest are well supplied with all of the mineral elements required in plant growth, and are exceptionally rich in phosphoric acid. As a rule, they are slightly acid in reaction, and, although substantial amounts of calcium are present, the application of finely crushed limestone is known to be of decided advantage in bringing them into a good state of cultivation.

LABoratory OF AgRicultural ChEMistry, UNIVERSITY OF IDAHO. 